- Notes -

\title{
Simplified Model for Extraction of 5-Hydroxymethylfurfural from Fructose: Use of Water/Oil Biphasic System under High Temperature and Pressure Conditions
}

\author{
Toshinori SHIMANOUCHI ${ }^{1}$, Yoshitaka KATAOKA ${ }^{1}$, Masahiro YASUKAWA ${ }^{2}$, Tsutomu ONO $^{3}$ \\ and Yukitaka KIMURA ${ }^{1 *}$ \\ 1 Graduate School of Environmental and Life Science, Okayama University, 3-1-1 Tsushimanaka,
} Okayama, Okayama 700-8530, Japan

2 Graduate School of Engineering, Kobe University, 1-1 Rokkodai-cho, Nada-ku, Kobe, Hyogo 657-8501

3 Graduate School of Natural Science and Technology, Okayama University, 3-1-1 Tsushimanaka, Okayama, Okayama 700-8530, Japan

(Received December 26, 2012; Accepted February 5, 2013)

\begin{abstract}
5-Hydroxymethylfurfural (HMF) was obtained from the dehydration of fructose under high temperature and pressure conditions $\left(180{ }^{\circ} \mathrm{C}\right.$ and $\left.10 \mathrm{MPa}\right)$. To avoid the decomposition of HMF in the bulk aqueous phase, we dehydrated fructose in the water / metyl isobuthyl ketone (MIBK) biphasic system. The HMF could be successfully extracted into the organic MIBK phase without further decomposition of HMF. We present a simplified model taking into consideration of the slug flow with the wall film to maximize the HMF yield in the MIBK phase. It was likely that the slug flow contributed to an increase in the surface-to-volume ratio for the mass transfer of HMF.
\end{abstract}

\section{Introduction}

5-Hydroxymethylfurfural (HMF) is one of the many potential platform chemicals for biorenewable chemicals production [1] because it is formed by dehydration of xylose, fructose and glucose [2-5]. Oxidation of HMF yields 2,5-furandicarbocylic acid (FDCA) which is a promising alternative monomer for terephthalic acid used to produce polyethylene terephthalate (PET) [6]. It has been reported that acid-induced production of HMF [1,3], the microwave-assisted hydrothermal degradation [7], or the usage of a heterogeneous catalyst such as ytterbium triflate [8], zeolite [9], and zirconium [10] were effective. It is well-known that HMF is an intermediate in the dehydration reaction for fructose and that there are many by-products in the reaction pathway from fructose to HMF [11]. In addition, since HMF is easily 
decomposed in water $[1,7,11]$, the recovery of HMF without its decomposition is therefore required.

The water / organic biphasic system has recently been investigated to recover HMF because it is well-known that no decomposition of HMF takes place in the organic phase [1]. It has been pointed out, however, that the batch reaction using a biphasic system requires refreshing of the organic phase by combining an evaporator with the extractor [1]. In recent studies, the continuous production of HMF in a biphasic system and its extraction from the aqueous phase has been investigated by using a mineral acid or zeolite catalysts [9] at temperatures greater than $450 \mathrm{~K}$. However, poor HMF partitioning into the organic phase required large amounts of solvent, suggesting the need for large energy expenditures to purify the diluted HMF products [1].

Recently, the efficacy of a microreactor for HMF production has been investigated [5]. Of the microreactors, a capillary microreactor is considered to be a promising system because the surface-to-volume ratio of the liquid-liquid biphasic system can be increased by the generation of slug flow in the capillary through a Y- or T-junction $[12,13]$. In fact, those systems exhibit excellent mass transfer characteristics and provide a well-defined interfacial area $[14,15]$. In our previous study, the continuous degradation of carbohydrates took place in the capillary tube $[16,17]$. Therefore, a combination of continuous degradation of substrates with the biphasic system might afford the improvement of yield and selectivity for HMF.

In this study, we aimed at the continuous production of HMF using a water / MIBK biphasic system to extract HMF into the organic MIBK phase. We assumed slug flow to promote the interfacial area between water and the MIBK phase and developed a simplified mass transfer / reaction model. Finally, we simply investigated the validity of the model by comparison with the experimental data.

\section{Experimental}

\subsection{Materials}

D(-)-Fructose (99+\%) and methyl isobuthyl ketone (4-methyl-2-pentanone; MIBK) were purchased from Wako Pure Chemical Industry. Ltd. (Osaka, Japan). 5-hydroxymethyl-2-furaldehyde (99\%) was purchased from Sigma Aldrich (Tokyo, Japan). Other chemical reagents were of analytical grade. Polyetheretherketone (PEEK) tubes were obtained from GL Science, Co. Ltd. (Tokyo, Japan).

\subsection{Set up of the reaction system}

The flow system used in this study is shown in Figure 1(a). In short, $10 \mathrm{wt} \%$ of fructose with 0.025 $\mathrm{mol} / \mathrm{L} \mathrm{HCl}$ was injected to mix with the organic MIBK solvent. The mixture was incubated in a heating bath $\left(180{ }^{\circ} \mathrm{C}\right)$ and thereafter cooled to $20{ }^{\circ} \mathrm{C}$. The pressure was elevated by controlling the back pressure valve. The residence time was determined by the flow rate.

In the batch system (Figure 1(b)), $6.0 \mathrm{~mL}$ of solution containing $0.1 \mathrm{~mol} / \mathrm{L} \mathrm{HCl}$ and $10 \mathrm{wt} \%$ fructose was added to the reaction cell. Thereafter, the reaction cell was placed in the oil bath to increase the temperature to $180{ }^{\circ} \mathrm{C}$. The reaction was monitored for $400 \mathrm{sec}$ to quantify the amount of 
HMF in the MIBK phase.

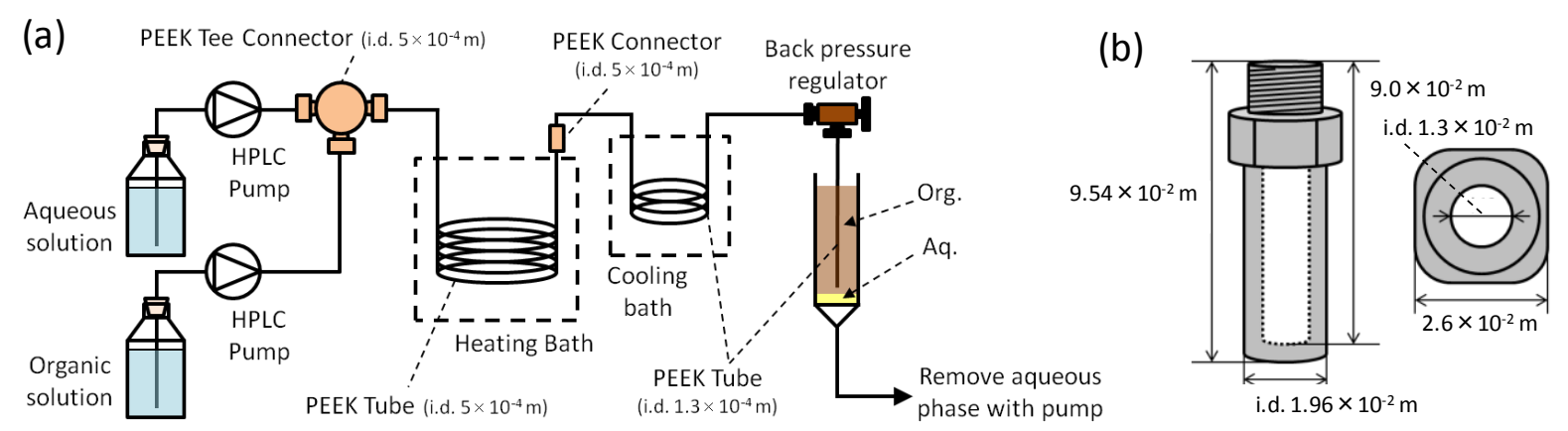

Figure 1. Experimental instruments for HMF production using (a) the flow system and (b) the batch system.

(a)

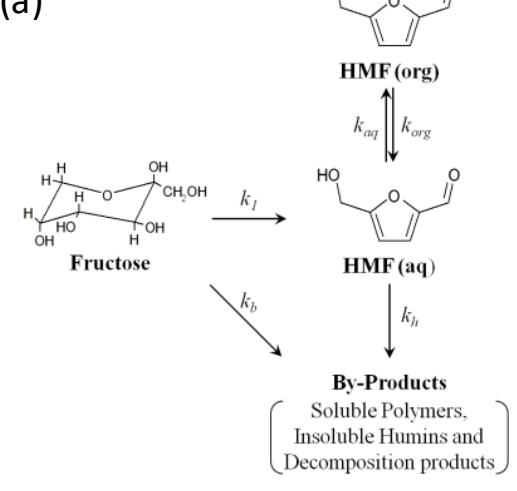

(b)

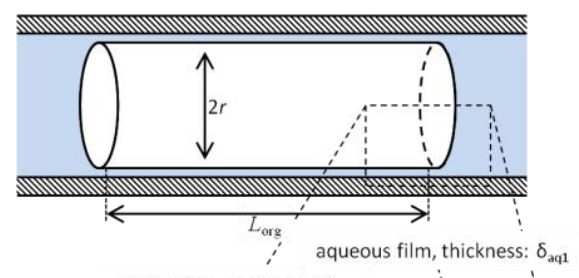

organic film, thickness: $\delta_{0}$

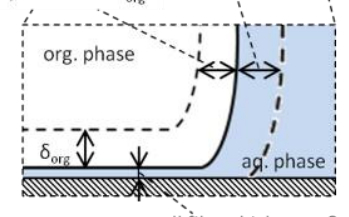

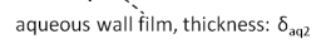

(c)

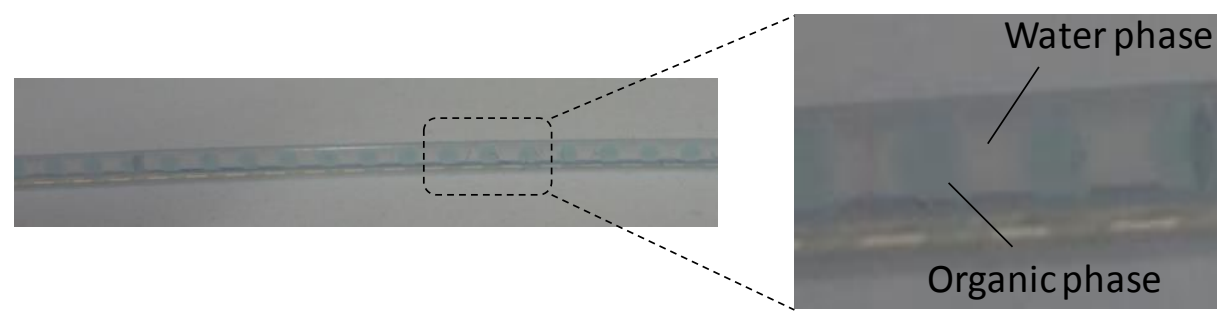

Figure 2. (a) Reaction process in this study, (b) Slug flow and the interface with the liquid film, (c) slug flow in a polytetrafluoroethylene (PTFE) tube.

\subsection{Determination of the HMF concentration}

The sample obtained from the reaction was analyzed by high performance liquid chromatography. The column used was a COSMOSIL 5C18-AR-II Packed Column $(4.6 \times 250 \mathrm{~mm}$, Nacalai Tesque Co. Ltd., Japan). We added $5 \mu \mathrm{L}$ of the sample into the column (equibrated at $40{ }^{\circ} \mathrm{C}$ ) at a flow rate of $1.0 \mathrm{~mL} / \mathrm{min}$. The mobile phase was $\mathrm{MeOH} / \mathrm{H}_{2} \mathrm{O}=20 / 80$ (wt / wt). The HMF in the sample was detected by a peak at $254 \mathrm{~nm}$ of wave length, by using the photo diode array detector (SPD-M20A, Shimadzu Co. Ltd.). The peaks derived from the water and the MIBK phases were eluted at 10 and $45 \mathrm{~min}$. 


\subsection{Theoretical section: Continuous production of HMF and its extraction from the organic phase}

We assumed the slug flow with the wall film in the tube, as shown in Figure 2(b). This is because the slug flow was observed under low temperature conditions, as shown in Figure 2(c).

Assuming a linear driving force approximation as previous reported [13], the mass transfer rate of HMF from the aqueous to the organic phase can be described as:

$$
W_{a q}=\left(\frac{A_{1} D_{a q}}{\delta_{a q 1}}+\frac{A_{2} D_{a q}}{\delta_{a q 2}}\right)\left([H M F]_{b}-[H M F]_{i}\right)
$$

where $\delta_{\text {aq1 }}$ and $\delta_{\text {aq2 } 2}[\mathrm{~m}]$ are the thickness of film at the bulk aqueous phase and at the wall, respectively. $D_{\text {aq }}$ $\left[\mathrm{m}^{2} / \mathrm{s}\right]$ is the diffusion coefficient of HMF in the film at the bulk aqueous phase. The subscriptions $\mathrm{b}$ and $\mathrm{i}$ represent the bulk aqueous phase and the interface of wall, respectively.

Likewise, the rate of mass transfer of HMF from the interface to the organic phase, $W_{\text {org }}[\mathrm{mol} / \mathrm{s}]$, is written as follows.

$$
W_{\text {org }}=\frac{\left(A_{1}+A_{2}\right) D_{\text {org }}}{\delta_{\text {org }}}\left([\overline{H M F}]_{i}-[\overline{H M F}]_{b}\right)
$$

where $\delta_{\text {org }}[\mathrm{m}]$ is the thickness of the film at the bulk organic phase. $D_{\text {org }}\left[\mathrm{m}^{2} / \mathrm{s}\right]$ is the diffusion coefficient of HMF in the film at the bulk organic phase.

The rate of mass transfer of HMF from the aqueous to the organic phase at the interface, $W_{\mathrm{ex}}[\mathrm{mol} / \mathrm{s}]$, is expressed as follows.

$$
W_{e x}=\left(A_{1}+A_{2}\right)\left(k_{a q}[H M F]_{i}-k_{\text {org }}[\overline{H M F}]_{i}\right)
$$

Herein, if $W_{\mathrm{ex}}=0$ under the distribution equilibrium state of HMF between the aqueous and the organic phase, the equilibrium constant for HMF between the aqueous and organic phase, $K_{\text {ex }}$, can be obtained from eq. (3), yielding eq. (5) by using eqs. (3) and (4).

$$
\begin{aligned}
K_{e x} & =\frac{k_{a q}}{k_{\text {org }}}=\frac{[\overline{H M F}]_{b, e q}}{[H M F]_{b, e q}} \\
W_{e x} & =\left(A_{1}+A_{2}\right) k_{a q}\left([H M F]_{i}-\frac{[\overline{H M F}]_{i}}{K_{e x}}\right)
\end{aligned}
$$

Under steady state $\left(W_{\text {aq }}=W_{\text {org }}=W_{\text {ex }}\right)$, one can obtain the following reaction rate for HMF as follows.

$$
-r_{H M F}=\frac{[H M F]_{b}-\frac{[\overline{H M F}]_{b}}{K_{e x}}}{\frac{\delta_{a q 1} \delta_{a q 2}}{\left(A_{1} \delta_{a q 2}+A_{2} \delta_{a q 1}\right) D_{a q}}+\frac{1}{\left(A_{1}+A_{2}\right) k_{a q}}+\frac{\delta_{o r g}}{\left(A_{1}+A_{2}\right) D_{o r g}} \frac{1}{K_{e x}}}
$$

In this study, we assumed that the by-product was present only in the bulk aqueous phase and that neither further oxidation nor decomposition of HMF occurred in the organic phase. Under those 
assumptions, the mass balance can be described as given below:

$$
[\overline{H M F}]_{\mathrm{b}}=\frac{V_{a q}}{V_{\text {org }}}\left([F]_{\mathrm{b}, 0}-[F]_{\mathrm{b}}-[H M F]_{\mathrm{b}}-[\mathrm{Bp}]_{\mathrm{b}}\right)
$$

The above reaction rate for HMF can be re-written as:

$$
-r_{H M F}=\frac{(1+\beta)[H M F]_{\mathrm{b}}-\beta\left([F]_{\mathrm{b}, 0}-[F]_{\mathrm{b}}-[\mathrm{Bp}]_{\mathrm{b}}\right)}{\alpha}
$$

where the parameters $\alpha$ and $\beta$ are as follows:

$$
\begin{aligned}
\alpha & =\frac{\delta_{a q 1} \delta_{a q 2}}{\left(A_{1} \delta_{a q 2}+A_{2} \delta_{a q 1}\right) D_{a q}}+\frac{1}{\left(A_{1}+A_{2}\right) k_{a q}}+\frac{\delta_{o r g}}{\left(A_{1}+A_{2}\right) D_{o r g}} \frac{1}{K_{e x}} \\
\beta & =\frac{V_{a q}}{V_{\text {org }}} \frac{1}{K_{e x}}
\end{aligned}
$$

In this study, the volume ratio $\left(\mathrm{V}_{\mathrm{aq}} / \mathrm{V}_{\text {org }}\right)$ was 0.8 . The rate of the decomposition of fructose and the production of by-products are described by simple first-order kinetics.

$$
\begin{aligned}
& \frac{d[F]_{\mathrm{b}}}{d t}=-k_{f}[F]_{\mathrm{b}} \\
& \frac{d[\mathrm{Bp}]_{\mathrm{b}}}{d t}=k_{b}[F]_{\mathrm{b}}+k_{h}[H M F]_{\mathrm{b}}
\end{aligned}
$$

where the rate constant $k_{\mathrm{f}}$ for fructose conversion was assumed to be related to the two rate constants (the reaction rate constant for the production of HMF from fructose, $k_{1}$, and for the production of by-product from fructose):

$$
k_{f}=k_{1}+k_{b}
$$

For the batch reaction in a monophasic system, eqs. (11) to (14) are sufficient to analyze the rate of production of the substrate and HMF.

$$
\frac{d[H M F]_{\mathrm{b}}}{d t}=k_{1}[F]_{\mathrm{b}}-k_{h}[H M F]_{\mathrm{b}}
$$

\section{Results and Discussion}

\subsection{Determination of the kinetics of HMF production}

In the first series of experiment, we preliminarily determined the variation in the value of the reaction rate constant as shown in Figure 2(a), by using the batch type reaction cell (Figure 1(b)). The elevation of the temperature in the batch type reaction cell was investigated by using the correlations with respect to natural convection. It was then found that the time required to reach to $180{ }^{\circ} \mathrm{C}$ was $180 \mathrm{~s}$. In response to the temperature, the variation in concentration for fructose and HMF occurred after $180 \mathrm{~s}$. Their concentrations in the aqueous solution after $180 \mathrm{~s}$ from the start of the reaction are shown in Figure 3(a). The resulting rate constants were estimated by using eqs. (11)-(14). The obtained rate constants are $k_{f}=1.56 \times 10^{-2} \mathrm{~s}^{-1}, k_{1}=$ $9.93 \times 10^{-3} \mathrm{~s}^{-1}, k_{b}=5.67 \times 10^{-3} \mathrm{~s}^{-1}$, and $k_{h}=5.18 \times 10^{-3} \mathrm{~s}^{-1}$. The decomposition rate constant of fructose 
estimated from its conversion $\left(k_{\mathrm{f}}\right)$ was larger than that for the microwave-assisted conversion of fructose in the absence of catalysts $\left(k_{\mathrm{f}}=6.5 \times 10^{-4} \mathrm{~s}^{-1}\right)$ [7].

The continuous production of HMF in the water / MIBK biphasic system was analyzed by using the flow system (Figure 1(a)). The rate of [HMF] production in both the aqueous and the organic phases is shown in Figure 3(b). A slight difference in $[\mathrm{HMF}]$ concentration between the aqueous and the organic phase was observed. There is a possibility that this resulted from the partition behavior of HMF between both phases. The rate of appearance of $[\mathrm{HMF}]$ in both phases was then analyzed by numerical calculation using eqs. (6) to (13) to determine the partition behavior of HMF between both phases $\left(K_{\mathrm{ex}}\right)$. For simplification, the diffusivity of HMF in the bulk aqueous phase, that in the organic phase, and the thickness of the wall film were assumed to be $10^{-10} \mathrm{~m}^{2} / \mathrm{s}, 10^{-9} \mathrm{~m}^{2} / \mathrm{s}$, and $10^{-6} \mathrm{~m}$, according to the previous literature [13]. The curve fitting with the experimental data gave the $\beta$ value as defined in eq. (10). The $K_{\text {ex }}$ value was thereby roughly estimated to be 1.0 , which is smaller than $K_{\text {ex }}=7.1$ for furfural [3], possibly due to the presence of the hydrophilic hydroxyl group. Therefore, it is considered that the small difference in $[\mathrm{HMF}]$ concentration between both phases resulted from the $K_{\text {ex }}$ value being nearly unit.

\subsection{Possible contribution of slug flow to HMF production and selectivity}

HMF can be in general obtained from the dehydration of glucose and fructose. It has been reported that the fructose conversion in subcritcal water was linearly correlated with the yield of HMF, meaning that HMF formation is a quite robust reaction [7]. The same is true for glucose conversion [8]. Such a trend can be seen in Table 1. Therefore, conversion during a short reaction time is required to achieve a high yield (a)

(b)
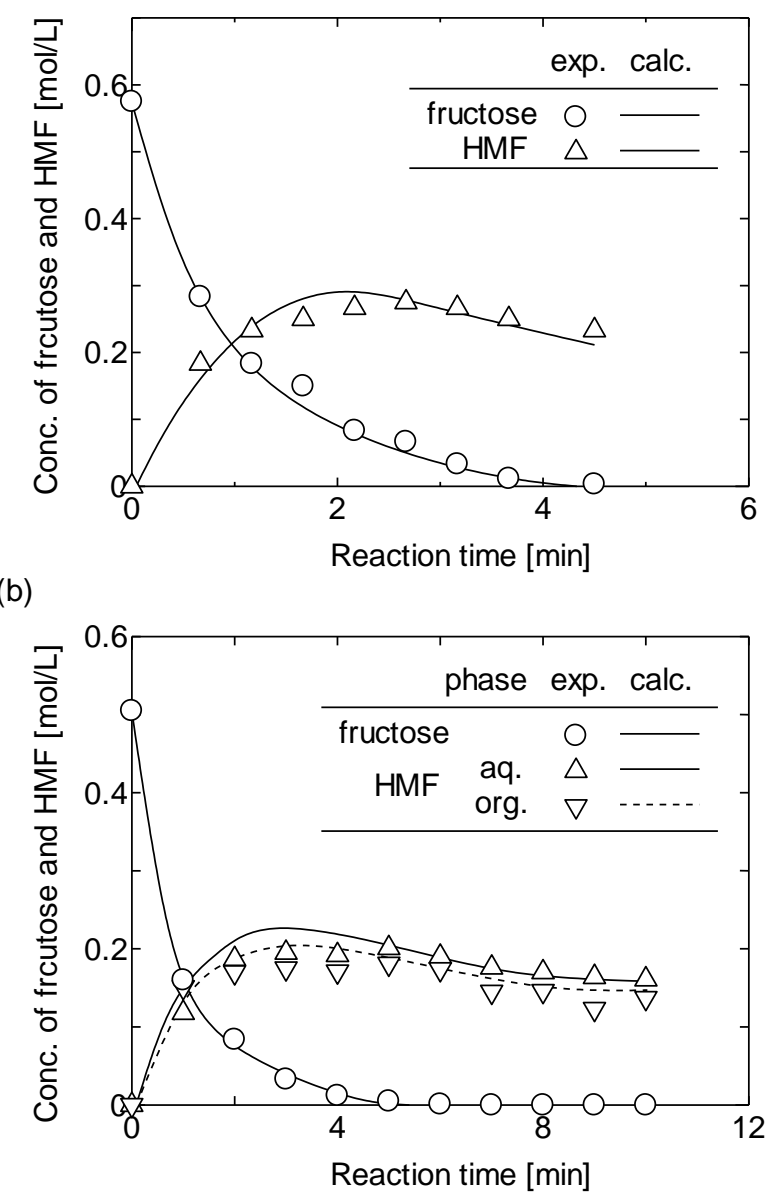

Figure 3. Rate of change of fructose and HMF concentrations in (a) the batch system and (b) the flow system. Reaction conditions are: (a) $[\mathrm{HCl}]_{0}=$ $0.10 \mathrm{~mol} / \mathrm{L}$; (b) $[\mathrm{HCl}]_{0}=0.0250 \mathrm{~mol} / \mathrm{L} . \mathrm{V}_{\mathrm{aq}} / \mathrm{V}_{\text {org }}=$ 0.8. Reaction temperature was $180{ }^{\circ} \mathrm{C}$. of HMF.

As shown in Table 1, heterogeneous catalysts such as an ion exchange resin (entry 4) or $\mathrm{Yb}(\mathrm{OTf})_{3}$ 
(entry 10) did not achieve a rapid conversion of the substrate because of the long reaction time required. Overall, a homogeneous catalyst such as $\mathrm{HCl}$ resulted in a short reaction (at most $10 \mathrm{~min}$ ). In the case of $\mathrm{HCl}(0.1-0.25 \mathrm{~mol} / \mathrm{L})$ as catalyst (entries 2,3,5,7), high conversion of fructose was observed (50 91\%). Meanwhile, the absence of the $\mathrm{HCl}$ catalyst resulted in no conversion (entry 1 ) or in mostly low conversion and yield $(<50 \%)$ in the case where the microwave-assisted heating was used (entries 6 and 9$)$. In contrast, the flow system presented here (entry 8) could achieve a high conversion ratio (93\%) and yield (84\%) of $\mathrm{HMF}$ in spite of the low concentration of $\mathrm{HCl}(0.025 \mathrm{~mol} / \mathrm{L})$, whereas the selectivity for $\mathrm{HMF}(90 \%)$ was also comparable with other systems. If HMF production in the flow system is considered as a robust reaction as well as the batch reaction system, a high concentration of $\mathrm{HCl}$ is required. Therefore, as no decomposition of HMF takes place in the organic phase, the improvement of both yield and selectivity of HMF is probably because the excellent mass transfer of HMF might be achieved through slug flow with a large surface-to-volume ratio. Although further investigation will be required, the $\alpha$ value defined as in eq.

(9) would give an insight on the effect of slug flow.

Table 1. Reaction yield of HMF under various conditions.

\begin{tabular}{|c|c|c|c|c|c|c|c|c|c|c|}
\hline Substrate & Entry & $\begin{array}{l}\text { Batch }(\mathrm{B}) \\
\text { / Flow }(\mathrm{F})\end{array}$ & Solvent & $\begin{array}{l}\text { Temp. }\left[{ }^{\circ} \mathrm{C}\right], \\
\mathrm{P}[\mathrm{MPa}]\end{array}$ & $\begin{array}{l}\text { Reaction } \\
\text { time }\end{array}$ & Catalyst & $\begin{array}{l}\text { Conve } \\
\text {-rsion } \\
{[\%]}\end{array}$ & $\begin{array}{l}\text { Yield of } \\
\mathrm{HMF} \\
{[\%]}\end{array}$ & $\begin{array}{l}\text { Selectivity } \\
\text { of HMF } \\
{[\%]}\end{array}$ & Ref \\
\hline \multirow[t]{8}{*}{ Fructose } & 1 & B & water & $\begin{array}{l}180^{\circ} \mathrm{C} \\
10 \mathrm{MPa}\end{array}$ & $10 \mathrm{~min}$ & None & 0 & 0 & - & $\begin{array}{l}\text { This } \\
\text { study }\end{array}$ \\
\hline & 2 & B & water & $\begin{array}{l}180^{\circ} \mathrm{C} \\
\text { A.P. }{ }^{a}\end{array}$ & $\begin{array}{l}2.5-3 \\
\min \end{array}$ & $\begin{array}{l}\mathrm{HCl} \\
0.25 \mathrm{~mol} / \mathrm{L}\end{array}$ & 50 & 29 & 51 & [1] \\
\hline & 3 & B & $\begin{array}{l}\text { water/ } \\
\text { MIBK }\end{array}$ & $\begin{array}{l}180^{\circ} \mathrm{C} \\
\text { A.P. }\end{array}$ & $\begin{array}{l}2.5-3 \\
\min \end{array}$ & $\begin{array}{l}\mathrm{HCl} \\
0.25 \mathrm{~mol} / \mathrm{L}\end{array}$ & 91 & 56 & 60 & [1] \\
\hline & 4 & B & $\begin{array}{l}\text { water/ } \\
\text { MIBK }\end{array}$ & $\begin{array}{l}90^{\circ} \mathrm{C} \\
\text { A.P. }{ }^{\text {a }}\end{array}$ & $8-16 \mathrm{~h}$ & $\begin{array}{l}\text { Ion-exchan- } \\
\text { ge resin }\end{array}$ & 75 & 34 & 44 & [1] \\
\hline & 5 & B & water & $\begin{array}{l}185^{\circ} \mathrm{C} \\
17 \mathrm{bar}\end{array}$ & $1 \mathrm{~min}$ & $\begin{array}{l}\mathrm{HCl} \\
0.1 \mathrm{~mol} / \mathrm{L}\end{array}$ & 71 & n.d. ${ }^{\mathrm{d}}$ & 75 & [5] \\
\hline & 6 & B & water & $\begin{array}{l}180^{\circ} \mathrm{C} \\
1.3 \mathrm{MPa}\end{array}$ & $10 \mathrm{~min}$ & $\begin{array}{l}\text { None } \\
\text { (microwave) }\end{array}$ & $\begin{array}{l}18.4 \pm \\
3.9\end{array}$ & $\begin{array}{l}10.3 \pm \\
2.4\end{array}$ & $65.0 \pm 2.5$ & [7] \\
\hline & 7 & B & water & $\begin{array}{l}180^{\circ} \mathrm{C} \\
10 \mathrm{MPa}\end{array}$ & $3 \mathrm{~min}$ & $\begin{array}{l}\mathrm{HCl} \\
0.1 \mathrm{~mol} / \mathrm{L}\end{array}$ & 81 & 45 & 55 & $\begin{array}{l}\text { This } \\
\text { study }\end{array}$ \\
\hline & 8 & $\mathrm{~F}$ & $\begin{array}{l}\text { water/ } \\
\text { MIBK }\end{array}$ & $\begin{array}{l}180^{\circ} \mathrm{C} \\
10 \mathrm{MPa}\end{array}$ & $3 \mathrm{~min}$ & $\begin{array}{l}\mathrm{HCl} \\
0.025 \mathrm{~mol} / \mathrm{L}\end{array}$ & 93 & 84 & 90 & $\begin{array}{l}\text { This } \\
\text { study }\end{array}$ \\
\hline \multirow[t]{2}{*}{ Glucose } & 9 & $\mathrm{~B}$ & water & $\begin{array}{l}200^{\circ} \mathrm{C} \\
1.3-4 \mathrm{MPa}\end{array}$ & $10 \mathrm{~min}$ & $\begin{array}{l}\text { None } \\
\text { (microwave) }\end{array}$ & $\begin{array}{l}36.7 \pm \\
2.8\end{array}$ & $\begin{array}{l}11.7 \pm \\
1.0\end{array}$ & $50.2 \pm 4.4$ & [7] \\
\hline & 10 & B & $\begin{array}{l}\text { ionic } \\
\text { liquid }^{b}\end{array}$ & $\begin{array}{l}73^{\circ} \mathrm{C} \\
\text { A.P. }{ }^{a}\end{array}$ & $1.3 \mathrm{~h}$ & $\begin{array}{l}\mathrm{Yb}(\mathrm{OTf})_{3}{ }^{\mathrm{c}} \\
23 \mathrm{mg}\end{array}$ & n.d. ${ }^{-}$ & 52.1 & n.d. ${ }^{-}$ & [8] \\
\hline
\end{tabular}

a A.P. autonomous pressure, b Reaction was performed in [BMIM]Cl ionic liquid., c $\mathrm{Yb}(\mathrm{OTf})_{3}$ : ytterbium triflate, d: not determined

\section{Conclusion}

The combination of a water/MIBK biphasic system with slug flow having the wall film under the hydrothermal conditions permitted the continuous production of HMF and its extraction from the organic phase. This system could be roughly described by a simplified model taking into consideration of slug flow, 
which is the first attempt in this field to our knowledge. The yield of HMF and its selectivity were also relatively higher than for conventional approaches, suggesting an advantage for the present flow system.

\section{References}

1) Y.Roman-Leshkov, J. N. Chheda, J. A. Dumesic, Science, 312, 1933-1937 (2006).

2) F. S. Asghari, H. Yoshida, Ind. Eng. Chem. Res., 46, 7703-7710 (2007).

3) R. Weingarten, J. Cho, W. C. Conner, Jr. G.W. Huber, Green Chem., 12, 1423-1429 (2010).

4) S.E.Davis, L.R.Houk, E.C.Tamargo, A.K.Datye, R.J.Davis, Catalysis Today, 160, 55-60 (2011).

5) T. Tuercke, S. Panic, S. Loebbecke, Chem. Eng. Technol., 32, 1815-1822 (2009).

6) S.E. Davis, L.R. Houk, E.C. Tamargo, A.K. Datye, R.J. Davis, Catal. Today, 160, 55-60 (2011).

7) M. Moller, F. Harnisch, U. Schroder, Biomass \& Bioenergy, 39, 389-398 (2012).

8) S.P. Utami, N.S. Amin, Industrial Crops and Products, 41, 64-70 (2013).

9) P. Rivalier, J. Duhamet, C. Moreau, R. Durand, Catal. Today, 24, 165-171 (1995).

10) F.S. Asghari, H. Yoshida, Carbohydrate Res., 341, 2379-2387 (2006).

11) D. Klingler, H. Vogel, J. Supercritical Fluids, 55, 259-270 (2010).

12) A. Ghaini, A. Mescher, D.W. Agar, Chem. Eng. Sci., 66, 1168-1178 (2011).

13) E. Kamio, Y. Seike, H. Yoshizawa, H. Matsuyama, T. Ono, Ind. Eng. Chem. Res., 50, 6915-6924 (2011)

14) M.N. Kashid, Y.M. Harsh, D.W. Agar, Chem. Eng. J., 131, 1-13 (2007).

15) A.L. Dessimoza, L. Cavinb, A.K Renken, L. K.-Minsker, Chem. Eng. Sci., 63, 4035-4044 (2008).

16) C. Usuki, Y. Kimura, S. Adachi, Food Sci. Technol. Res., 13, 205-209 (2007).

17) C. Usuki, Y. Kimura, S. Adachi, Chem. Eng. Technol., 31, 133-137 (2008). 